\title{
Study of Descriptive Determinants of Moral Harassment at Work in a Factory in Senegal
}

\author{
Abou Sy ${ }^{*}$ (1), Ekué Kafui Kokou1, Jean Augustin Diegane Tine², Ndeye Amelie Makareme Sy33, \\ Aissatou Diallo1, Ibrahima Seck², Mor Ndiaye ${ }^{3}$, Taiwo Lateef Sheikh", Mamadou Habib Thiam \\ ${ }^{1}$ Department of Psychiatry, University Cheikh Anta DIOP, Dakar, Senegal \\ ${ }^{2}$ Department of Public Health, University Cheikh Anta DIOP, Dakar, Senegal \\ ${ }^{3}$ Department of Labor Medicine, University Cheikh Anta DIOP, Dakar, Senegal \\ ${ }^{4}$ Department of Psychiatry, Ahmadu Bello University, Zaria, Nigeria \\ Email: *abousypsy@yahoo.fr
}

How to cite this paper: Sy, A., Kokou, E.K., Tine, J.A.D., Sy, N.A.M., Diallo, A., Seck, I., Ndiaye, M., Sheikh, T.L. and Thiam, M.H. (2020) Study of Descriptive Determinants of Moral Harassment at Work in a Factory in Senegal. Health, 12, 106-117. https://doi.org/10.4236/health.2020.122009

Received: January 8, 2020

Accepted: February 7, 2020

Published: February 10, 2020

Copyright $\odot 2020$ by author(s) and Scientific Research Publishing Inc. This work is licensed under the Creative Commons Attribution International License (CC BY 4.0).

http://creativecommons.org/licenses/by/4.0/

\begin{abstract}
Introduction: Globalization and the attendant contemporary system of work organization, industrial competitiveness and workplace hostility could be a source of stress. Behaviors considered to be hostile tend to constitute the foundation on which moral harassment at work rests and contributes significantly to work place mental health. Methodology: We conducted a quantitative, cross sectional descriptive study between April 1 and June 30, 2018 at the Grands Moulins de Dakar "GMD". We used a questionnaire containing the socio-demographic data to which we added the Masson Meret and Steiner questionnaire called, "Ambiance in professional environment". We used the Epi info software for data entry and analysis. Results: Sample population was 100 subjects with average age of 42.18 years \pm 7.6 , a male predominance of $91 \%$ and average length of service in the company was 15.27 years \pm 10.1 . Hostile behavior was more frequently reported than stress, with $49 \%$ and $28 \%$ respectively. Among the hostile behavior we found criticism in the professional field in 35\% of the cases and rumors mongering was observed in $25 \%$ of the cases. The most reported stress symptom was general fatigue (45\%), hostile behavior was more common in males (40 - 49 years of age and those with more than 10 dependents). Of the officers who felt generally unwell, 78.9\% were victims of hostile behavior. Conclusion: Hostile behavior forms the basis of moral harassment at work and their devious nature makes them difficult to detect, this contrasts with its harmful consequences on the health of the staff. Potentially harmful workplace stress has become more frequently encountered in the contemporary workplace and has constituted an occupational hazard. The most common symptoms reported are feeling unwell and general fatigue.
\end{abstract}

\section{Keywords}

Bulling, Moral Harassment, Psychosocial Violence, Stress, Senegal 


\section{Introduction}

The term moral harassment is synonymous with other terms such as psychological abuse, mobbing and bulling [1]. Even if there is no consensus definition [2], the one proposed by Hirigoyen [3] Seems the most consensual. "Moral harassment at work is defined as any abusive conduct (gesture, word, behavior, attitude...) that undermines, by its repetition or systematization, the dignity or the psychic or physical integrity of a person, endangering the employment of the person or degrading the working climate. The emergence of the concept of moral harassment took place against the backdrop of globalization and industrial competitiveness, which increasingly confronted workers with job requirements, organizational constraints, and an intensification of work, all often associated with uniform management method that takes less account of individual psychic specificities [4] [5]. This led to the individuation of work to the detriment of the community, suggesting recognition "on merit" [2]. This type of organization is characterized by a sense of responsibility at work that contrasts with a lack of symbolic recognition [6]. In this sense, it is possible to understand that the suffering generated by work can lead to a "malaise" [7]. Studies have theorized the mechanisms behind bullying, therefore it appears there is a need to integrate the harassed and harassing, couple with the organizational factors to better understand this phenomenon [6] [8] [9]. There may be no disagreement between two colleagues [9] but rather the manner of organization of the company may condone negative actions that may significantly affect both the individual and organizational [2]. According to Poilpot-Rocaboy the notion of "repetition of behavior" is essential [1], it emphasizes among other things the nature of the behavior, the focus on a target and the results of the behavior. Moral harassment from the hierarchy descending vertical or bossing is the most common, there are other types of harassment; the horizontal harassment perpetuated by colleagues whereas mixed harassment combines the first two forms. On the other hand, the vertical upward harassment is done by employees on their hierarchical superior [3].

In moral harassment it is important to individualize the executioner or agressor and the victim, to analize the environment and scrutinize the consequences and especially the mechanisms that underlie it. Several studies have attempted to determine a typical personality of victims or perpetrators, however they revealed that there was no typical personality even-if certain traits could be dominant [9]. Therefore, it has become necessary to focus on the behavior that underlies the phenomenon of hostile behavior that is characterized by its subjectivity [8]. Various studies have identified set of hostile actions within the company which constitute the base of the moral harassment [1] [10] [11]; these are grouped into 5 classes that aim to isolate the victim, to prevent him from expressing himself, to make him lose his self-esteem, to prevent him from working properly and to compromise his health. The works of Poilpot-Rocaboy [12] on the other hand have led to a modeling in 4 components: 1) the individual and organizational determinants 2) the behavior of moral harassment 3 ) the responses of the victim 
and the organization and 4) the individual consequences. The peculiarity of this approach is that an isolated act can constitute psychological violence [13] [14] while their persistence over time defines moral harassment. However in some countries, depending on the law, an isolated act may constitute harassment [15].

Studies have shown the extent of this scourge of moral harassment within modern working environment to be on a global scale [1] [2] [4] [16] but there is dearth of published work within the African continent. This development may be due to lack adequate consideration of the rights of workers, lack of attention to the health of workers generally and specifically absence of policy and institutionalization of work place mental health among African countries. Our work was aimed at studying the existence and frequency of these hostile acts within a Senegalese company.

\section{Objectives}

\subsection{General Objective}

The general objective of this work was to study the determinants of moral harassment in a Senegalese company.

\subsection{Specific Objectives}

Our specific objectives were:

- Determine the level of stress in a Senegalese factory.

- Determine the frequency of exposure to hostile actions in a Senegalese factory.

- To study factors related to the occurrence of psychological violence in a company in Senegal.

\section{Material and Methods}

\subsection{Study Framework}

We conducted a study in a Senegalese factory called "Grands Moulin de Dakar". It is a factory that is specialized in the food sector located in Dakar. The factory "Les Grands Moulins de Dakar" is the first Senegalese factory in the production of flour. It started its activities in 1954. It is positioned as the main flour-producing factory for the production of bread. the latter is one of the bases of food in Senegal. The GMD located in Hann Bel-Air in the Dakar port area supplies flour to bakers, pastry chefs, and households. The staff is made up of three socio-professional categories, namely managers, supervisors and laborers.

\subsection{Type of Study}

We conducted a quantitative, cross-sectional, descriptive and analytical study between April 1 and June 30, 2018.

\subsection{Study Population}

The study population was the entire staff of the Grands Moulins de Dakar 
"GMD". The total number of workers was 194 and were stratified into three consisting of; Managers, Supervisors and Laborers.

\subsection{Inclusion Criteria}

We included in our study staff who worked in Dakar for more than six months and agreed to participate in the study.

\subsection{Exclusion Criteria}

We exclude from our study those who were absent during the data collection period or who refused to participate in the study.

\subsection{Data Collection}

We used a self administered questionnaires. This questionnaire was split in two; the first part sought sociodemographic variables while the second part consisted of the moral harassment questionnaire of Masson Meret and Steiner [17] called "Atmosphere in the workplace", which is in the form of a set of 33 items from the 45 items of the Leyman questionnaire. It assesses exposure to psychological violence at work. The variables that were used for this work did not take into account the notion of duration and frequency of negative actions.

\subsection{Data Entry and Analysis}

Data entry was done by EPI INFO version 2011. The same software is used for data analysis. We conducted a descriptive and bivariate analysis. Statistical tests were performed with a risk of error $\alpha$ equal to $5 \%$.

\subsection{Ethical Considerations}

Before starting the study, we obtained permission from the company management and the support of the company doctor. After the agreement of the management, the human resources department sent us the list of the 194 employees of the company.

We met with each staff on individual interview basis during which the purpose of the study was explained to them their informed consent was obtained, we also affirmed the confidentialty of the information obtained and anonymous nature of the study.

\section{Results}

\subsection{Description of Patients}

Out of a total of 168 staff members, 118 accepted to participate in the study. Then fifty workers refused to participate in the study without giving reasons. One hundred and five questionnaires were collected and 100 was returned.

Our study population was predominantly male at $91 \%$ with average age of $42.18 \pm 7.6$ while $86 \%$ were married. The average duration of employment in the company was 15.27 years \pm 10.1 , whereas the average duration on a position was 
8.4 years \pm 7.3 . Almost all the staff $(94 \%)$ were on indefinite term contracts.

Although $28 \%$ of the subjects reported being stressed based on the KARASECK score, almost half of our study population (49\%) reported being the target of hostile actions. The victim was physically isolated either by putting him on a job that kept him away from other workers (8\%) most of the time, or being ignored or by not responding to enquiries $(10 \%)$ or behaved as if the victim does not exist (19\%) (see Figure 1). The victim can be forced to be silent by negative criticism of private life (13\%) or professional performance $(35 \%)$. Victims may also be subject of verbal threats $(9 \%)$, telephone threats $(8 \%)$ or in writing $(2 \%)$ (see Figure 2). The paroetrator could also target the self-esteem of the victim in various ways, the most common in our study was to launch rumors about the victim (25\%) or slander the victim (21\%) (see Figure 3). Among the actions aimed at preventing the victim from working properly included asigning the victim responsibility below his/her rank or qualification (15\%) (see Figure 4). Nearly half of our study population (49\%) thought that the working conditions affected their health. The most reported symptom was general fatigue (45\%) (see Figure 5).

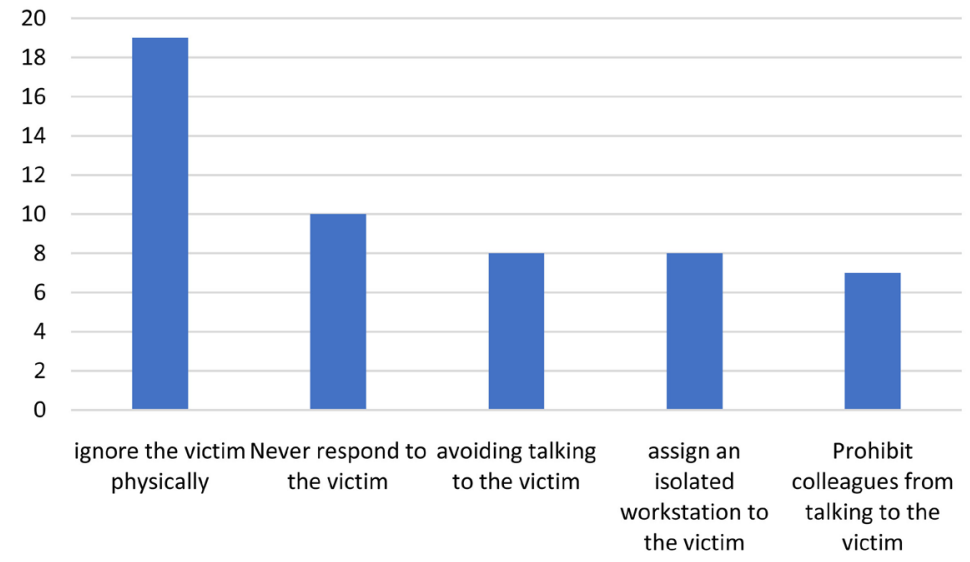

Figure 1. Distribution of hostile acts to isolate the victim.

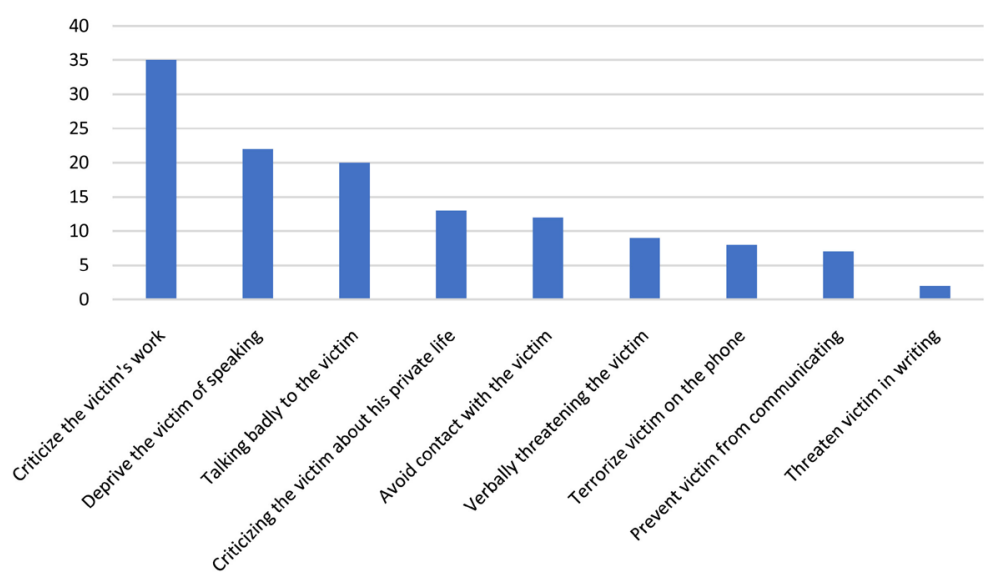

Figure 2. Distribution of actions aimed at preventing the employee from expressing himself. 


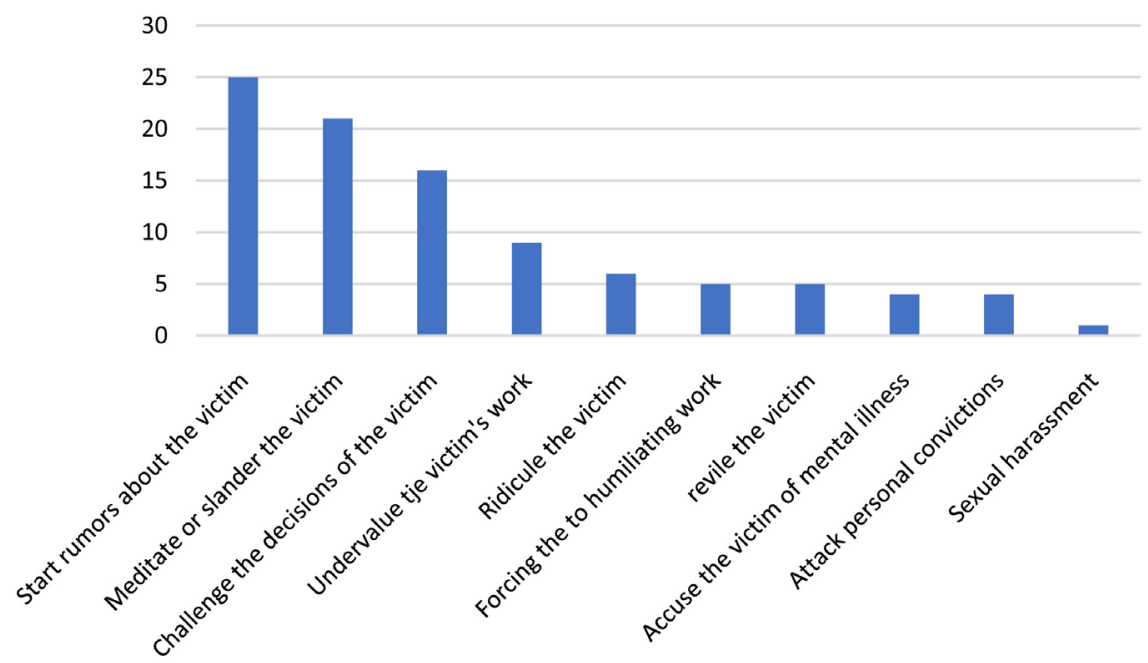

Figure 3. Distribution of actions with the objective of losing self-esteem to the victim.

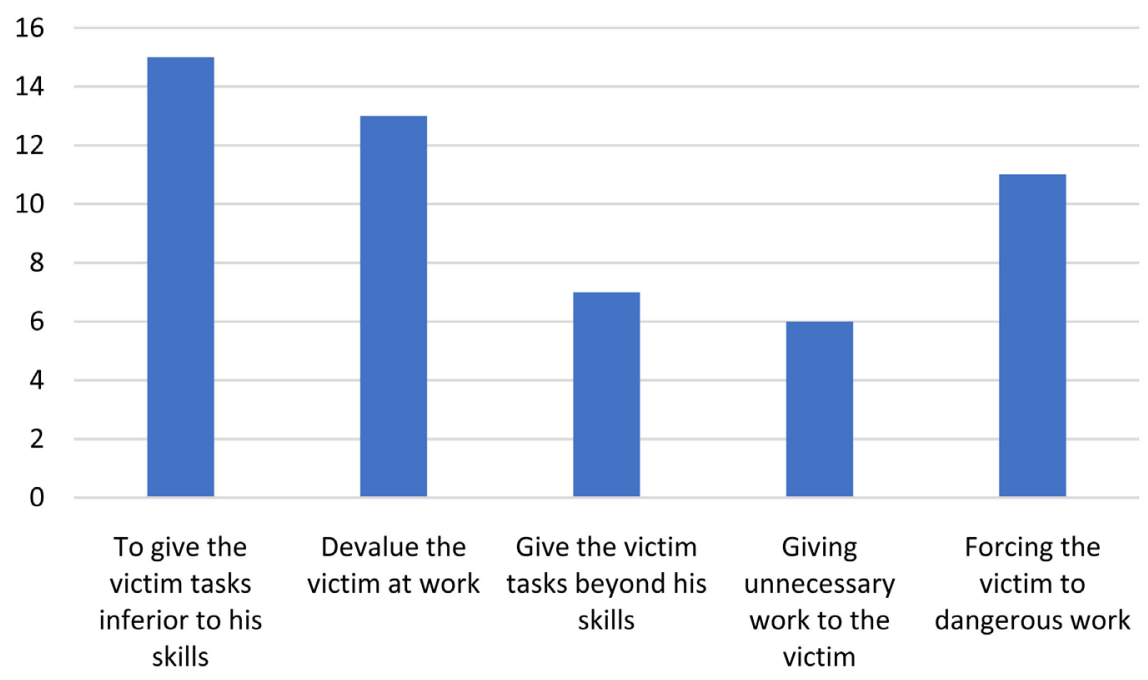

Figure 4. Distribution of actions to prevent the victim from working properly.

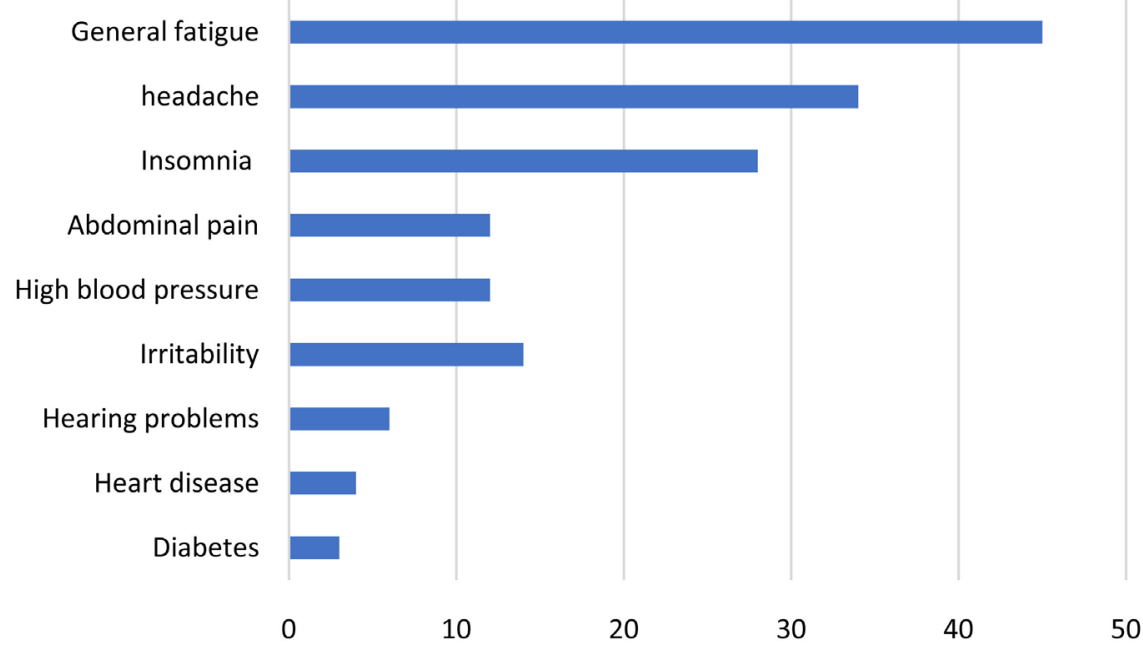

Figure 5. Health problems reported by employees. 


\subsection{Analysis of Hostile Acts by Patient Characteristics}

Exposure to hostile behavior varied by gender; it was $52.7 \%$ for male and $11.1 \%$ for women, this difference was statistically significant ( $p$ value $=0.017$ ). In terms of age, hostile actions were more common among officers aged 40 - 49 years, however, the difference was not statistically significant. Hostile actions were more common in subjects with more than 10 people under their supervision. this difference was however not statistically significant. Hostile actions were more common among employees with less than 15 years duration of service in the company, this difference was statistically significant. Of the subjects who reported being stressed based on the Karasek score, $60.7 \%$ were victims of hostile behavior but the difference was not statistically significant. Among the employees who were followed up by the company doctor, $66.7 \%$ were victims of hostile acts, this was statistically significant. Among staff who had an overall sense of unease, $78.9 \%$ were victims of hostile action. This was statistically significant. The most common health consequences were insomnia, headaches and general fatigue. Of the employees who were feeling fatigued, $62.2 \%$ were victims of hostile acts and this was statistically significant (see Table 1).

Table 1. Distribution of hostile behavior according to socio-demographic and clinical characteristics.

\begin{tabular}{|c|c|c|c|c|c|c|}
\hline & & \multicolumn{4}{|c|}{ Actual hsotiles behaviour } & \multirow{3}{*}{$P$ value } \\
\hline & & \multicolumn{2}{|c|}{ Yes } & \multicolumn{2}{|c|}{ No } & \\
\hline & & $\mathrm{N}$ & $\%$ & $\mathrm{~N}$ & $\%$ & \\
\hline \multirow{2}{*}{ Gender } & Male & 48 & 52.7 & 43 & 47.3 & \multirow{2}{*}{0.017} \\
\hline & Female & 1 & 11.1 & 8 & 88.9 & \\
\hline \multirow{4}{*}{ Age } & $20-29$ years & 13 & 46.4 & 15 & 53.6 & \multirow{4}{*}{0.417} \\
\hline & $30-39$ years & 11 & 45.8 & 13 & 54.2 & \\
\hline & $40-49$ years & 17 & 48.6 & 18 & 51.4 & \\
\hline & $\geq 50$ years & 8 & 61.5 & 5 & 38.5 & \\
\hline \multirow{3}{*}{$\begin{array}{l}\text { According to the number } \\
\text { of people in charge }\end{array}$} & $<5$ persons & 2 & 0.2 & 8 & 0.8 & \multirow{3}{*}{0.413} \\
\hline & $5-10$ persons & 20 & 47.6 & 22 & 52.4 & \\
\hline & $\geq 10$ persons & 27 & 56.3 & 21 & 43.8 & \\
\hline \multirow{2}{*}{ Seniority in the company } & $<15$ years & 44 & 84.6 & 8 & 15.4 & \multirow{2}{*}{0.0001} \\
\hline & $\geq 15$ years & 5 & 10.4 & 43 & 89.6 & \\
\hline \multirow{4}{*}{ KARASEK Score } & Actif & 24 & 51.1 & 23 & 48.9 & \multirow{4}{*}{0.140} \\
\hline & Détendu & 2 & 20.0 & 8 & 80.0 & \\
\hline & Passif & 6 & 40.0 & 9 & 60.0 & \\
\hline & Stress & 17 & 60.7 & 11 & 39.3 & \\
\hline \multirow{2}{*}{ Medical monitoring } & Actual & 18 & 66.7 & 9 & 33.3 & \multirow{2}{*}{0.024} \\
\hline & No & 31 & 42.5 & 42 & 57.5 & \\
\hline \multirow{2}{*}{ Global feeling } & ill being & 15 & 78.9 & 4 & 21.1 & \multirow{2}{*}{0.011} \\
\hline & well being & 34 & 39.5 & 47 & 60.5 & \\
\hline \multirow{2}{*}{ Insomnia } & Yes & 18 & 64.3 & 10 & 35.7 & \multirow{2}{*}{0.056} \\
\hline & No & 31 & 42.1 & 41 & 56.9 & \\
\hline \multirow{2}{*}{ Headache } & Yes & 21 & 61.8 & 13 & 38.2 & \multirow{2}{*}{0.066} \\
\hline & No & 28 & 42.4 & 38 & 57.6 & \\
\hline \multirow{2}{*}{ General fatigue } & Yes & 28 & 62.2 & 17 & 37.8 & \multirow{2}{*}{0.016} \\
\hline & No & 21 & 38.2 & 34 & 61.8 & \\
\hline
\end{tabular}




\section{Discussion}

Hostile actions are usually characterized by their sneaky and subjective character [17], they often take the form of verbal abuse [8]. In addition, there may be minor physical violence, ranging from jostling to intimidation. In our study the frequency of exposure to verbal abuse was $35 \%$, this is in the range reported by Di Martino [18] in his work, which ranged from 32.2\% in Bulgaria to 67\% in Australia. This violence was in the form of invectives in $20 \%$ of cases and criticisms on the private life of the employee (9\%). The workplace violence has the particularity of disrupting the victims' functioning and psychology, these are part of denial of recognition and disqualification leading to unjustified and progressive rejection [19]. Whereas the victim does not understand what is happening to him but finds himself/herself dealing with acts that are purposely designed to isolate him/her and to prevent him/her from self-expression. These actions persist into long-term activities with cyclical phases of harassment and reassurance: 1) the perpetrator reassures the victim after a violence act, 2) the victim hopes the violence is going to stop, but 3 ) when the victim is confident, violence occurs again) [1].

In our study, actions to prevent the victim to express themselves were found in $22 \%$ of cases, Delage [18] in a study conducted in Quebec found the same phenomenon in $33 \%$ of cases. This phenomenon of isolation is important insofar as it aims to cut the victim out of his environment. It is in this sense that these hostile acts constitute the foundation on which the mobbing develops. Another hostile act is to bring the victim into disrepute before his/her colleagues at work or in his/her private life. These actions are aim at depriving the victim of respect and self-esteem [19]. In our study, the frequencies of these behaviors were $25 \%$ and $13 \%$ respectively. Delage [18] in his works reported that $6 \%$ of victims reported impairment of performance at work, which is lower than our finding. On the other hand, actions aimed at private life was reported by $74 \%$ of victims. In our study, the most frequently reported hostile action was to assign the victim work below his qualifications (15\%). It should be noted that the Delage [18] in his study reported higher frequency. These targeted hostilities have led to the assertion that the major purpose of the inflicted violence is to control the victims. According to Grebot [9] the hold is at the heart of the harassment and can be exercised by different types of personality including the narcissistic personality, the obsessive personality can also use the hold to dominate the other in order to establish power and authority. The victim is more or less left to act, think and desire things as he/she sees fit, whereas the perpetrator exercises his/her power insidiously through permanent control and repeated intrusions that violate the privacy of the victim and breaks the limits of his/her inner space. Such that these types of personalities install their power within a permissive environment.

It should be noted that the perpetrator rarely acts alone and the lone target is also exceptional [9] [15]. According to the study conducted by Viaux [20], it was 
reported that in $45 \%$ of cases there are at least four perpetrators to a victim and in $87.5 \%$ of cases there are several victims of a perpetrator [20]. We also report similar results in this study, in fact, $49 \%$ of our study population say they are victims of harassment multiple perpetrators and this type of behavior multiple perpetrators and multiple victims is reflected in daily actions noted within the company. Thus, it is clear that bullying constitutes major mode hostility within the organization framework in the company. Although studies have tried to profile the perpetrators and victims [20], we however opined that there was a need to focus on the factors associated with these hostile acts.

In our series, among the 49 employees who were exposed to hostile acts we observed a male predominance with 48 men exposed against only 1 woman. The difference was statistically significant $(\mathrm{p}$ value $=0.017$ ) and similar results are found in the literature from Seiler and equally cited by Clausia [21]. It should be noted that most studies report a predominance of women [1] [11] [15]. The male predominance found in our study is related to our study to the field of activity of the organization. Beyond the variable results, the common point is that there is a parallelism between the gender and the exposure to the negative acts coming within the framework of the psychological violence [20].

In our study, agents aged 40 to 49 were most at risk, the same age groups are reported in studies conducted in France [9] [15] [20]. According to Grebot [9] in this context, they found that harassment appears as a real sanction and is borne out of deliberate desire to get rid of the oldest employees. This is a form of stigmatization underpinned by a depreciative recognition [19]. Because one is brought to think that with the age the premium of duration of service increases, so is the responsibility of the organization to the staff. At the same time, there is greater autonomy and less resistance to submission, in addition to this is the fact that it is more difficult to find a new job after 45 years. In our cultural context, employees tend to favor stability of employment and sense of job security, this is highlighted by the high number of employees with open-ended contracts, as such age is related to duration of service in the organization most often. Although we are tempted to link bullying with age, we have not found a statistically significant relationship. Just as we found in our study, it should be noted that other investigations have reported harassment among employees under 25 years of age, this is generally considered the point of starting their carrier activity and such staff are in a precarious status [22]. At the same time, hostile acts were more common among workers with less than 15 years of duration of and this was statistically significant ( $\mathrm{p}$ value $=0.0001$ ).

It is important to distinguish stress from moral harassment, in our work we report that the frequency of stress was lower than that of exposure to negative behaviors. These results highlight the place of bullying among the major psychosocial risks in business. However, we also observed that victims often do not relate their illness to the harassment they were exposed to, we found that, only $11 \%$ of our studied population thought they were exposed to actions that could affect their state of health, whereas a higher frequency $31 \%$ was reported by De- 
lage [16]. This difference can be explained by a better awareness of workers on the issue of moral harassment and its consequences in their study. On the other hand, the majority of those exposed to hostile actions (76.5\%) reported that they did not feel well, we believe that the loss of this feeling of well-being better reflects the situation of moral harassment. Other studies reported similar findings [11] [17] [23] [24]. We also observe that this sort of subjectivity was also reflected in other symptoms, in our study $62.2 \%$ of the staff exposed to the negative behaviors admitted to suffer from fatigue. Similar results are reported in the literature [23] [24]. The same is true of insomnia where $64.3 \%$ of subjects who reported insomnia episodes were exposed to hostile actions. Insomnia and fatigue have been reported in the literature as a warning sign of existence of psychological violence at work place [23]. The subjectivity of these symptoms may be an obstacle to the request for medical consultation. This leads to a situation of functional disability with the main psychopathological syndromes encountered namely burnout, depression, trauma and suicide [1] [4] [18] [23]-[28]. In our study population, $66.7 \%$ of the staff exposed to the negative behaviors consulted a doctor because of fatigue or stress, indeed other studies have reported these as warning symptoms that requires adequate attention [23] [24]. Fatigue (62.2\%) or stress (64.3\%) were reported in our study among harassed workers, these figures highlight the physician's role in screening for psychological violence within the company [11] [15] [23] [24]. Hirigoyen [8] reported a request for medical assistance of victims in the same proportions $65 \%$ with a satisfactory response rate was observed in $42 \%$ of cases. However, this request for help was lower among labor physicians, which was $39 \%$ with a satisfactory response rate of $13 \%$ of cases. According to Poilpot-Rocaboy [1]. This difference can be explained by the late request for help from the victim due to the cyclical insidious harassment which was embedded within the organization, we opine that the type of relationship between the doctor and his patient can be decisive.

\section{Conclusion}

Hostile behavior forms the basis of moral harassment at work and their devious nature makes them difficult to detect, this contrasts with its harmful consequences on the health of the staff. Potentially harmful workplace stress has become more frequently encountered in the contemporary workplace and has constituted an occupational hazard. The most common symptoms reported are feeling unwell and general fatigue. We emphasize that the occupational doctor has a major role to play in its detection and management.

\section{Conflicts of Interest}

The authors declare no conflicts of interest regarding the publication of this paper.

\section{References}

[1] Poilpot-Rocaboy, G. (2006) Bullying in the Workplace: A Proposed Model for Un- 
derstanding the Psychological Harassment Process. Research and Practice in Human Resource Management, 14, 1-17.

[2] World Health Organization (2003) Raising Awareness of Psychological Harassment at Work. Protecting Workers' Health Series No. 4, 40.

[3] Hirigoyen, M.F. (1998) Le harcelement moral au travail, La violence perverse au quotidien, Paris, Syros.

[4] Campos Izabel, C..M., Lizandra, D., Rafaela Luiza, T. and Roberto, M.C. (2012) Moral Harassment at Work Model and Inability. Work, 41, 2060-2067.

[5] Grazina Isabel, M.J. (2012) Moral Harassment at Work: The Relationship with Organizational Culture. Journal of Business and Retail Management Research, 7, $12-26$.

[6] Honneth, A. (2000) La lutte pour la reconnaissance. Les Éditions du Cerf, Paris, 232 p.

[7] Renault, E. (2004) L'expérience de l'injustice: reconnaissance et clinique de l'injustice, Paris, La Découverte, 412.

[8] Hirigoyen, M.F. (2016) Le harcèlement moral, un symptôme de la société moderne. Annales Médico Psychologiques, 7, 575-579. https://doi.org/10.1016/j.amp.2016.05.004

[9] Grebot, E. (2007) Harcèlement au travail: Identifier, prévenir, désamorcer. Edition d'Organisation, Paris, 196.

[10] Leymann, H. (1994) Mobbing, la persécution au travail, Paris, Seuil.

[11] Hirigoyen, M.F. (2001) Malaise dans le travail, Harcèlement Moral, Demeler le vrai du faux, Paris, La découverte et Syros.

[12] Poilpot-Rocaboy, G. (2000) Le processus de harcèlement professionnel, La revue française de gestion, Rennes, 31-51.

[13] Einarsen, S., Hoel, H., Zapf, D. and Cooper, C.L. (2011) The Concept of Bullying and Harassment at Work: The European Tradition. In: Bullying and Harassment in the Workplace: Developments in Theory, Research, and Practice, 2nd Edition, Stale Einarsen, Helge. https://doi.org/10.1201/EBK1439804896

[14] Faul, D. and Detroz, P. (2009) Harcèlement psychologique au travail: Processus relationnels et profils de victimes. Approche processuelle, intégrative et dynamique d'un phénomène complexe. Le travail humain, 2, 155-184. https://doi.org/10.3917/th.722.0155

[15] Leymann, H. (1996) MOBBING. La persecution au travail. Editions du Seuil, 213.

[16] Delage, D. (2006) La prévention du harcèlement psychologique: Agir a la source, développement d'un instrument de mesure. Mémoire présente a l'universite du Québec a Trois-Rivieres comme exigence partielle de la maitrise en administration des affaires.

[17] Masson-Maret, H. and Steiner, D.D. (2004) Climat de justice et harcèlement moral perspectives théoriques et outils de diagnostic. Psychologie du travail et des organisations, 10, 9-28. https://doi.org/10.1016/j.pto.2003.12.002

[18] Di Martino, V. (2002) Workplace Violence in the Health Sector-Country Case Studies Brazil, Bulgaria, Lebanon, Portugal, South Africa, Thailand, plus an Additional Australian Study: Synthesis Report. Programme conjoint OIT/CII/OMS/ISP sur la violence au travail, Genève.

[19] Renault, E. (2004) Reconnaissance, Institutions, Injustice. Revue du MAUSS, No. 23, 180-195. https://doi.org/10.3917/rdm.023.0180 
[20] Viaux, J.-L. and Bernaud, J.-L. (2001) Le harcèlement psychologique au travail: Une recherche nationale auprès des victimes. Pratiques Psychologiques, 4, 57-69.

[21] De Gasparo, C. (2003) Harcèlement moral et sexuel: Une approche sociologique. L'Harmattan. Cahiers du Genre, 2, 165-187. https://doi.org/10.3917/cdge.035.0165

[22] Saillard, C. and Sautejeau, V. (2000) Conditions de travail et sante des apprentis de moins de 18 ans de la Vienne. Rapport Observatoire Régional de la Santé Poitou Charentes No. 66.

[23] Conne-Perreard, E. (2006) Atteintes a la sante et harcèlement moral. Éthique \& Sante, 3, 102-105. https://doi.org/10.1016/S1765-4629(06)70572-4

[24] Grenier-Peze, M., et al. (2002) Approche pluridisciplinaire du harcelement moral. Documents pour le médecin du travail No. 90. 2eme trimestre. Reference INRS=TF 113.

[25] Chevrier, N. and Renon-Chevrier, S. (2004) L'epuisement professionnel: Vers des interventions organisationnelles. Psychologie Quebec, 39-40.

[26] Watson, W. (2005) Au travail! Vers une organisation en sante, 15 p.

[27] Dube, S. and Parent, M. (2004) Le cout croissant de la gestion des invalidites. Avantages, 41-44.

[28] Kivimaki, M., Virtanen, M., Vartia, M., Elovainio, M., Vahtera, J. and Keltikangas-Jarvinen, L. (2003) Workplace Bullying and the Risk of Cardiovascular Disease and Depression. Occupational and Environmental Medicine, 60, 779-783.

https://doi.org/10.1136/oem.60.10.779 